\title{
Europe plans convention on social impacts of biomedical technologies
}

Parls. The rights of the individual should take precedence over those of science and society, according to the draft of a proposed 'European Convention on Bioethics' released last week by the 32-member Council of Europe.

The proposed convention is being billed as the first international treaty specifically to address the potential risks of progress in biology and medicine to the rights and freedom of human individuals, as well as to the future of the species.

Achieving consensus on bioethical issues from 32 European countries is an impossible task, and the content of the convention is inevitably little more than a lowest common denominator of member states' wishes.

Nevertheless, supporters of the convention argue that it provides an umbrella of broad fundamental principles that member states are likely to agree to - probably next year - and then tailor to their national legislation, for example by adding greater detail or stricter terms.

The backbone of the convention is a statement that "safeguarding the fundamental rights and freedoms of individuals, and in particular their integrity, dignity and identity" is its main goal.

The safeguards it proposes rely on the principle of free and informed consent to treatments and experiments, protection against unlawful interference with the human body, a ban on using the body - or its

parts - for "financial gain", and restrictions on predictive genetic testing.

The convention also formally introduces the notion that society now needs to set the limits to scientific research. Scientific liberty is needed, it says, but only where this remains compatible with the "protection of humans"; developments in biology and medicine must be used only for the "benefit of present and future generations".

Member states failed to agree on a definition of a "person" or a "human being", opting instead for the principle that "human dignity must be respected from the beginning of life". Similarly, the draft convention does not take a position on what should be done with surplus embryos, or under what conditions, if any, preimplantation diagnosis of embryos conceived in vitro should be permitted. Both issues dominated the recent debate over bioethics legislation in France (see Nature 369, 599; 1994).

A Council of Europe official says these issues will be tackled during the drafting of protocols designed to complete the convention. One such protocol, due to be completed by 1996, will address all aspects of

\section{Future brightens for space station}

Washington. The dark clouds that had been hanging over the future of the international space station appear to have lifted following last week's decision by the US House of Representatives to approve next year's funding of $\$ 2.1$ billion for the project.

The vote, which passed by an overwhelming margin, follows a vigorous campaign by the Clinton administration to make Russia's proposed participation in the project a key foreign policy objective.

The decision, approved by 278 votes to 155 , virtually ensures the space station's survival in Congress until next summer, and may well take the controversial project on which $\$ 11$ billion has already been spent - - beyond the point of no return.

The space station passed last year by just one vote. But once members saw it was heading for victory this year, they realized that voting against would merely antagonize the administration, and the vote became a landslide.

But the underlying factors behind the space station's easy victory were the state of US relations with Russia and the mood of Congress on deficit reduction (see Nature 368, 279; 1994).

Russia appears more politically stable than widely expected when its participation in the space station was proposed last autumn. And the deficit-cutting Congress which killed off the Superconducting Super Collider last summer has returned to its more natural state of reciprocal favours and shameless 'pork-barrelling'.

The bill that funds NASA now moves on to the Senate, where Senator Barbara Mikulski (Democrat, Maryland) has promised to give NASA a hard time unless the administration offers her backing on other unrelated matters. But the medium-term prospects for the space station have seldom looked so bright.

Colin Macilwain 